\title{
Differentiation of Varroa jacobsoni Oud populations by random amplification of polymorphic DNA (RAPD)
}

\author{
B Kraus *, G Hunt \\ Department of Entomology, UC Davis, Davis, CA 95616, USA
}

(Received 2 November 1994; accepted 17 March 1995)

\begin{abstract}
Summary - Specimens of Varroa jacobsoni collected from Apis mellifera L colonies in California, Texas and Germany and specimens collected from $A$ cerana Fab colonies in Malaysia were compared by means of random amplification of polymorphic DNA (RAPD). A high percentage of monomorphic bands indicated low genetic variability among and within populations of the parasite. It was not possible to distinguish mites collected in California and mites collected in Texas. Mites collected in the USA were distinguishable from mites collected in Germany by 3 specific markers. Mites collected from $A$ mellifera in the USA and Germany were distinguishable from mites collected from $A$ cerana in Malaysia by 27 and 24 specific markers. RAPD proved to be a valuable tool especially for further interpopulation studies of $V$ jacobsoni.
\end{abstract}

Varroa jacobsoni Oud / Apis mellifera L / Apis cerana Fab / RAPD marker / genetic variability / geographical variability

\section{INTRODUCTION}

The parasitic mite Varroa jacobsoni Oud is today's most important honey bee parasite and causes colony losses almost world wide. Originally a parasite of the Asian honeybee Apis cerana Fab the mite was detected on A mellifera in the 1960s (Delfinado, 1963; De Jong et al, 1982). Importation of commercial $A$ mellifera colonies into areas with an $A$ cerana population brought the previously allopatric bee species into contact (Ruttner and Maul, 1983) and allowed $V$ jacobsoni to switch to the new host. While the populations of the parasite reach only a small size within colonies of $A$ cerana (Koeniger et al, 1983) and do not damage the colony, infested $A$ mellifera colonies die. According to new models of host-parasite coevolution the mite can

* Present address: Universiteit Utrecht, Vakgroep Vergelijkende Fysiologie Projectgroep Ethologie en Socio-oecologie, Centrumgebouw Noord, Padualaan 14, De Uithof, Postbus 80086, NL-3508 TB Utrecht, The Netherlands. 
develop towards less virulence or extirpate its new host as well (Levin and Pimentel, 1981; Anderson and May, 1982). Numerous studies have been conducted which deal with factors influencing the virulence of $V$ jacobsoni such as climate (De Jong et al, 1984; Ritter and De Jong, 1984; Moretto et al, 1991) and bee race (Moritz and Hänel, 1984; Moretto et al, 1991; Otten, 1991). Unfortunately, little is known about the population structure of $V$ jacobsoni from different countries and continents. In a study conducted with allozymes it was not possible to distinguish European and Asian mites (Biasolo, 1992) and in another study conducted with cuticular hydrocarbons it was not possible to distinguish European and North American mites (Nation et al, 1992). Multivariate morphometric techniques revealed some geographic variation in $V$ jacobsoni (Grobov et al, 1980; Delfinado-Baker and Houck, 1989). In order to test a model of coevolution of $A$ mellifera and $V$ jacobsoni a method is required that allows reliable differentiation between mites of different origin. The objective of the present study was to test RAPD (random amplification of polymorphic DNA) as a method to reveal such differences.

\section{MATERIALS AND METHODS}

\section{Mite material}

The adult females used in this study were collected from A mellifera colonies in California, Weslaco (Texas) and Oberursel (Germany) and from A cerana colonies in Tenom (Borneo, Malaysia). The Californian population included samples of 5 mites each from 14 feral honey bee colonies and 11 pesticide-treated commercial colonies located within the Californian Central Valley or at the Californian Central Coast (San Francisco area, Monterey). The host colonies were located within an area $100 \mathrm{~km}$ north, $400 \mathrm{~km}$ south, $100 \mathrm{~km}$ west and $200 \mathrm{~km}$ east of Sacramento. Mites were, if possible, obtained from commercial colonies located within the same area as feral honey bee colonies used as mite sources. Nineteen mites obtained from Texas originated from 11 colonies. Nine mites collected in Germany originated from one colony. Twenty-four mites obtained from Malaysia originated from 3 colonies. Samples collected in the USA were kept on liquid nitrogen immediately after removing the parasite from its host bee with a paint brush and subsequently kept at $-70^{\circ} \mathrm{C}$. Samples collected in Germany or Malaysia were kept in ethanol (95\%).

\section{Mite DNA}

DNA was isolated according to the modified method of Hunt and Page (1992). A single individual was ground in a microcentrifuge tube; $50 \mu \mathrm{l}$ of lysis buffer $(1 \mu \mathrm{g} / \mathrm{ml}$ proteinase $\mathrm{K}, 1 \%$ hexadecyltrimethyl ammoniumbromide, $0.75 \mathrm{M} \mathrm{NaCl}$, $10 \mathrm{mM}$ EDTA, $50 \mathrm{mM}$ Tris- $\mathrm{HCl}, \mathrm{pH}$ 8) were added while grinding. The homogenate was incubated at $60^{\circ} \mathrm{C}$ for $1 \mathrm{~h}$ and $30 \mu \mathrm{l}$ of lysis buffer containing 1.5 $\mathrm{M} \mathrm{NaCl}$ were added. After that the homogenate was extracted twice by an equal volume of phenol/chloroform/octanol (25:24:1) and chloroform/octanol (24:1). The phases were separated by spinning $10 \mathrm{~min}$ and $2 \mathrm{~min}$ at full speed in a microcentrifuge. The DNA was precipitated by adding $110 \mu \mathrm{l}$ ethanol and $10 \mu \mathrm{l} 3 \mathrm{M} \mathrm{NaAc}, \mathrm{pH}$ 5. The DNA was dried and resuspended in $10 \mu \mathrm{l}$ TE (10 mM Tris- $\mathrm{HCl}, \mathrm{pH} 8,1 \mathrm{mM}$ EDTA). Quantification was conducted using a fluorometer (Hoefer Instruments model TKO-100). DNA was dissolved in TE $(10 \mathrm{mM}$ Tris- $\mathrm{HCl}, \mathrm{pH} 8,0.3 \mathrm{mM}$ EDTA) to achieve a concentration of $1 \mathrm{ng}$ DNA per $\mu$ l.

The banding patterns of bee samples and mite samples were compared with 2 primers. Mite samples and bee samples shared no bands. This result demonstrates that only DNA from the Varroa mite but no DNA from the hemolymph of the host was analyzed. The banding pattern of mites kept in ethanol at room temperature for a period of 10 months was not distinguishable from the banding pattern of fresh material kept on liquid nitrogen for $24 \mathrm{~h}$.

\section{Primers}

The primers used (Operon Inc) were 10 nucleotides in length and approximately $60 \% \mathrm{G} / \mathrm{C}$ 
in content. Nomenclature for RAPD loci indicates the primer kit designation given by Operon Inc and the molecular weight of the band in kilobases. A total of 224 primers were screened with 3 samples each; 72 primers with a clear banding pattern were chosen for further screening with 2 samples from feral honey bee colonies and 2 samples from pesticide-treated commercial colonies. Since no polymorphisms were detected primers were chosen again for a clear banding pattern which means several highly reproducible bright bands and only few dim bands. All mite samples collected in California were examined with the following primers: A3, A6, B14, C12, D2, G1, H1, J13, J16, K11, M11, P3, R5, T2, W3, X4. Twentyfour primers with a clear banding pattern were chosen for further screening with 2 samples each from California, Germany and Malaysia. Those primers revealing the highest number of polymorphic bands were chosen for further studies. All mite samples collected in Texas, Germany and Malaysia were examined with the following primers: A3 (5'AGTCAGCCAC), A6 (5'GGTCCCTGAC), B14 (5'TCCGCTCTGG), C12 (5'TGTCATCCCC), H1 (5'GGTCGGAGAA), J13 (5'CCACACTACC), J16 (5'CTGCTTAGGG), K11 (5'AATGCCCCAG), P3 (5'CTGATACGCC), W3 (5'GTCCGGAGTG), X4 (5'CCGCTACCGA).

\section{DNA amplification}

RAPD marker reactions were conducted according to the modified method of Williams et al (1990). Reaction volumes of $12.5 \mu$ l contained $10 \mathrm{mM}$ Tris $\mathrm{HCl}(\mathrm{pH} \mathrm{8.2)}, 50 \mathrm{mM} \mathrm{KCl}, 2 \mathrm{mM}$ $\mathrm{MgCl}_{2}, 0.1 \mathrm{mM}$ each dATP, dCTP, dTTP and dGTP, $0.2 \mu \mathrm{M}$ primer, 0.5 units of Taq DNA polymerase and 1 ng DNA-template. Amplifications were performed in a thermal cycler (Perkin-Elmer Cetus model 480 ) programed for 48 cycles of 1 min at $94^{\circ} \mathrm{C}, 1 \mathrm{~min}$ at $35^{\circ} \mathrm{C}$ and $2 \min$ at $72^{\circ} \mathrm{C}$. The products were resolved by electrophoresis. Gels contained $1 \%$ Synergel and $0.7 \%$ ultrapure agarose (BRL). After staining with ethidium bromide, gels were photographed with polaroid film.

With the exception of primer $\mathrm{P} 3$, only the absence or presence of bands that were monomorphic within a population was scored. Presence (absence) of a band means that the band is present (absent) in all examined individuals of same origin. Bands referred to as specific markers are bands which were present in all samples of one origin and absent in all samples of another origin. Only in case of P3 were differences in brightness scored.

\section{Statistical analysis}

As a measure of the strength of association between different populations Jaccard's index was calculated (Ludwig and Reynolds, 1988). This index is equal to the proportion of the bands shared by 2 populations out of all bands scored. The index reaches a maximum of 1 when populations are not distinguishable.

Table I. Absence and presence of RAPD markers in different populations of $V$ jacobsoni.

\begin{tabular}{|c|c|c|c|}
\hline Band (kb) & USA & Germany & Malay \\
\hline B14-1.3 & + & + & - \\
\hline B14-1.4 & + & + & - \\
\hline B14-2.0 & + & + & - \\
\hline B14-2.2 & - & - & + \\
\hline C12-0.92 & + & - & - \\
\hline C12-1.2 & + & + & - \\
\hline C12-1.4 & - & - & + \\
\hline H01-0.49 & - & - & + \\
\hline H01-0.92 & + & + & - \\
\hline $\mathrm{J} 13-0.22$ & - & - & + \\
\hline J13-0.72 & + & + & - \\
\hline J13-2.0 & + & - & - \\
\hline J13-2.2 & - & - & + \\
\hline J13-2.3 & + & - & - \\
\hline J13-2.4 & + & + & - \\
\hline J16-0.47 & - & - & + \\
\hline J16-1.3 & - & - & + \\
\hline $\mathrm{J} 16-1.7$ & + & + & - \\
\hline $\mathrm{J} 16-1.9$ & + & + & - \\
\hline $\mathrm{K} 11-0.73$ & + & + & - \\
\hline P03-0.67 & + & + & - \\
\hline W03-0.46 & + & + & - \\
\hline W03-0.49 & - & - & + \\
\hline W03-0.60 & + & + & - \\
\hline W03-1.2 & - & - & + \\
\hline X04-1.1 & + & + & - \\
\hline$\times 04-1.8$ & + & + & - \\
\hline
\end{tabular}

Only primers which revealed differences between mites of different origin are listed. $+=$ present; $-=$ absent. 


\section{RESULTS}

\section{Differentiation of $\mathrm{V}$ jacobsoni of different origin}

Mites sampled from $A$ cerana in Malaysia showed 9 bands not present in mites sampled from A mellifera in Germany or the USA (table I). Mites obtained from Germany or the USA showed 15 bands not present in mites from Malaysia. Three bands were only found in mites collected in the USA while all bands present in mites obtained from Germany and Malaysia were present in the samples collected in the USA. All bands shared between mites obtained from the USA and Malaysia were also present in mites collected in Germany.
No specific bands were found in mites collected from Californian feral honey bee colonies compared to mites collected from Californian pesticide-treated commercial colonies, or mites collected in Texas (table II). Mites obtained from the USA were distinguishable from mites collected in Germany by 3 specific markers. Mites obtained from the USA and Germany were distinguishable from mites collected in Malaysia by 27 and 24 specific markers. Some $76 \%$ of all scored bands ( $n=111,11$ primers) were found to be common to all populations.

Primer $\mathrm{P} 3$ revealed the same banding pattern at $0.41,0.45$ and 0.52 kilobases in all samples from Germany, Malaysia and $5 \%$ of the samples from feral honey bee colonies (table III, fig 1). All samples from Texas and $94 \%$ of the samples from California showed the same banding pattern, which differed

Table II. Degree of association between populations of $V$ jacobsoni.

$\begin{array}{lccc}\text { Population } & \begin{array}{c}\text { Number of } \\ \text { individuals }\end{array} & \begin{array}{c}\text { Jaccard's } \\ \text { index }\end{array} & \begin{array}{c}\text { Number of bands } \\ \text { (number of primers) }\end{array} \\ \text { California feral-California commercial } & 75-55 & - & \\ \text { California-Texas } & 130-19 & 1.00 & 133(16) \\ \text { USA-Malaysia } & 149-23 & 1.00 & 102(11) \\ \text { USA-Germany } & 149-9 & 0.76 & 111(11) \\ \text { Germany-Malaysia } & 9-23 & 0.97 & 102(11) \\ & & 0.78 & 109(11)\end{array}$

Table III. Frequency of bands of different brightness revealed by primer P3 in different populations of $V$ jacobsoni.

Band

California

Texas

Germany

Malaysia

$\begin{array}{ccc}118 \text { out of } & 4 \text { out of } 75 & 3 \text { out of } 50 \\ 125 \text { samples } & \text { samples } & \text { samples from } \\ \text { total } & \text { from feral } & \text { commercial } \\ & \text { colonies } & \text { colonies }\end{array}$

Faint

Bright

Bright

Bright

Faint

Bright

Bright
Faint
Faint

Faint
Bright
Faint

Faint

P03.0.52

Faint

Bright

Faint 


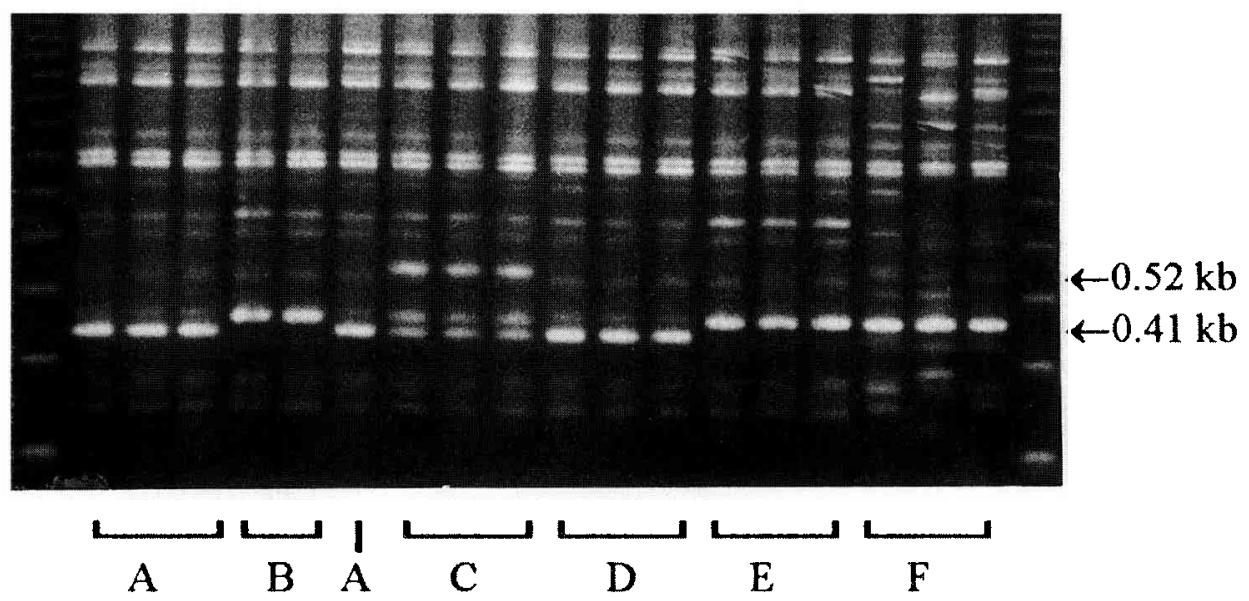

Fig 1. RAPD banding pattern among $V$ jacobsoni samples of different origin, primer $\mathrm{P} 3$ (table III). Samples A, 4 individuals with banding pattern common in California. Samples B, 2 individuals from feral colonies with rare banding pattern. Samples $C, 3$ individuals from commercial colonies with rare banding pattern. Samples D, 3 individuals from Texas. Samples E, 3 individuals from Germany. Samples $F, 3$ individuals from Malaysia. The ladder is a $123 \mathrm{~kb}$ ladder.

from the banding pattern of mites from Germany and Malaysia. Six percent of the samples obtained from pesticide-treated commercial colonies showed a banding pattern only found in those samples. The distribution of these bands in the feral population and commercial colonies in California was significantly different $\left(2 \times 3\right.$ contingency $\chi^{2}=64$. $5, p<0.001)$.

\section{Genetic variability within populations of $\mathrm{V}$ jacobsoni}

Ten clearly scorable bands were found to be polymorphic within 125 Californian samples compared to 133 scored monomorphic bands ( $7 \%, 0.056 \%$ per individual). In 23 samples from Malaysia 8 bands were found to be polymorphic compared to 94 scored monomorphic bands $(9 \%, 0.39 \%$ per individual). In 19 samples from Texas 4 bands were found to be polymorphic compared to 102 scored monomorphic bands (4\%, $0.21 \%$ per individual). In 9 samples from Germany 1 band was found to be polymorphic com- pared to 99 scored monomorphic bands ( $1 \%, 0.11 \%$ per individual).

\section{DISCUSSION}

$\checkmark$ jacobsoni samples collected from 25 different sources within California and all sources in Texas were found to generate highly similar banding patterns. The genetic variability of the parasite among different populations also was found to be very low. Absence or presence of specific bands that were monomorphic within populations, clearly distinguished mites from different sources.

$\checkmark$ jacobsoni collected in California were not distinguishable from mites collected in Texas. The identity of banding patterns from mites collected from 2 geographic regions in the USA shows the reliability of the banding patterns scored. Mites obtained from Germany were distinguishable from $V$ jacobsoni obtained from Texas or California with specific markers but the populations shared 
a high percentage of bands. The high similarity of German mites and North American mites might suggest European origin of North American mites but might also only reflect low genetic variability in $V$ jacobsoni. A final answer to the question of the origin of $V$ jacobsoni in the USA is only possible by an examination of mites obtained from South America. Mites collected in Malaysia from A cerana proved to be clearly different from mites collected from $A$ mellifera in Europe or the USA. This result might be caused by strong differences between Malaysian mites and mites in areas where European and South American mites originated from, and/or clear differences between $V$ jacobsoni parasitizing different bee species. Delfinado-Baker and Houck (1989) suggested that mites parasitizing the 2 species represent different biotypes. Sample sizes used in this study are too low to allow conclusions concerning general differences between Varroa mites from California, Texas, Germany and Malaysia. However, the desribed differences in banding patterns of mites of the examined specific origins demonstrate the value of the method.

The detected differences in frequency of bands (primer P3) in the feral honey bee population and the population of pesticidetreated commercial colonies in California can be explained in several ways. Possible explanations are for example differences between $V$ jacobsoni in both bee populations, a geographic effect or deviations from common allele frequencies (Hardy-Weinberg law) caused by high levels of inbreeding in colonies with a small mite population.

The results of the present study prove that random amplification of polymorphic DNA is a valuable tool for interpopulation studies and intrapopulation studies on $V$ jacobsoni. The high percentage of monomorphic bands shared by mites of different origin causes difficulties in finding differences, especially when intrapopulation studies are conducted, but detection of spe- cific markers is also possible in this species. A disadvantage of the RAPD method is that bands shared between populations may have no genetic identity. However, in the future sequencing of bands and crosses have to be conducted to overcome this problem.

\section{ACKNOWLEDGMENTS}

We wish to thank RFA Moritz and 2 anonymous referees for reading and improving the manuscript, A Collins for collecting mites in Texas, T Kühnert for collecting mites in Germany and $N$ Koeniger for collecting the Malaysian samples. This study was made possible by the Deutsche Forschungsgemeinschaft (grant No Kr 1275/1 2), the California State Beekeepers' Association, and California Department of Food and Agriculture contracts No 92-0418 and No 92-0615.

\section{Résumé - Différenciation des popula- tions de Varroa jacobsoni Oud au moyen de la technique des RAPD. L'acarien Var-} roa jacobsoni Oud est actuellement le parasite le plus dangereux pour l'abeille. En utilisant une technique d'analyse enzymatique, il a été possible de différencier des acariens originaires d'Asie de ceux provenant d'Europe (Biasolo, 1992). En revanche, en analysant la composition en hydrocarbures cuticulaires, il n'a pas été possible de distinguer les acariens européens de ceux d'Amérique du Nord (Nation et al, 1992). Dans le but, d'une part, de proposer un modèle de coévolution de l'abeille Apis mellifera et de $V$ jacobsoni et, d'autre part, de comparer les résultats des différents travaux portant sur la recherche d'abeilles résistant aux acariens, il est nécessaire de mettre au point une méthode permettant la caractérisation d'acariens d'origines différentes. Ce travail présente les résultats d'une étude réalisée au moyen de la technique des RAPD ; il porte sur 14 colonies d'abeilles sauvages et 11 colonies commerciales traitées par un acaricide de Californie ( 5 acariens dans chaque 
colonie), 1 colonie d'Allemagne ( 9 acariens), 3 colonies d'A cerana de Malaisie ( 24 acariens). La variabilité génétique de l'acarien est très faible. Pour les acariens de Californie, seulement $7 \%$ des 143 bandes observées étaient polymorphiques. De même chez les acariens d'A cerana, seulement $9 \%$ des 102 bandes étaient polymorphiques. On a trouvé 3 marqueurs spécifiques qui permettent de distinguer les varroas provenant des États-Unis de ceux provenant d'Allemagne. Les varroas provenant d'Apis mellifera ont été dinstingués de ceux provenant d'A cerana par 27 (Malaisie/États)Unis) et 24 (Malaisie/Allemagne) marqueurs. Aucune différence n'a été trouvée entre les varroas collectés au Texas et ceux collectés en Californie. La méthode des RAPD représente donc un outil performant en particulier pour les études interpopulations chez $V$ jacobsoni.

Varroa jacobsoni Oud / Apis mellifera L / Apis cerana Fab / marqueurs RAPD / variabilité génétique / variabilité géographique

Zusammenfassung - Unterscheidung
von Populationen der Milbe Varroa jacobsoni Oud mittels RAPD. Die Milbe Varroa jacobsoni Oud ist der momentan weltweit ökonomisch wichtigste Bienenparasit. Es ist bisher weder mit Hilfe von Allozymen (Biasolo, 1992) noch durch Analyse von Kohlenwasserstoffen (Nation et al, 1992) gelungen, aus verschiedenen Erdteilen stammende Varroamilben zu unterscheiden. Für Studien zur Wirt-Parasitkoevolution von $A$ mellifera und $V$ jacobsoni ebenso wie beim Vergleich der Ergebnisse von Studien zur Varroaresistenzzucht bei der Honigbiene ist es von großer Wichtigkeit, Milben unterschiedlicher Herkunft unterscheiden und ihren Verwandschaftsgrad bestimmen zu können. In der vorliegenden Untersuchung wurden jeweils 5 Milben aus 14 wildlebenden Honigbienenvölkern und
11 pestizidbehandelten kommerziellen Völkern aus Kalifornien, 19 Milben aus Texas (11 Völker), 9 Milben aus der Bundesrepublik Deutschland (1 Volk) und 24 vom ursprünglichen Wirt $A$ cerana abgesammelte Milben ( 3 Völker) mittels random amplification of polymorphic DNA (RAPD) untersucht. Die genetische Variabilität des Parasiten erwies sich als sehr gering. Bei den aus Kalifornien stammenden Milben traten bei insgesamt 143 ausgewerteten Banden nur $7 \%$ polymorphe Banden auf. Auch bei den vom ursprünglichen Wirt $A$ cerana abgesammelter Milben traten bei nur $9 \%$ der insgesamt 102 ausgewerteten Banden Polymorphismen auf. In den Vereinigte Staaten gesammelte Milben unterschieden sich von den aus der Bundesrepublik Deutschland stammenden Milben durch 3 spezifische Marker. Die Proben aus den Vereinigte Staaten und der Bundesrepublik Deutschland waren durch 27 bzw 24 spezifische Marker von Milben zu unterscheiden, die vom ursprünglichen Wirt $A$ cerana stammten. Milben aus Texas und Kalifornien waren nicht unterscheidbar. Die RAPD-Methode erwies sich als wertvolle Methode, insbesondere bei Interpopulationsstudien an $V$ jacobsoni. Die geringe genetische Variabilität des Parasiten macht mit dieser Methode gefundene Unterschiede zwischen Milbengruppen relativ aussagekräftig und erlaubt daher Aussagen selbst bei geringer Probengröße.

\section{Varroa jacobsoni Oud / Apis mellifera / Apis cerana Fab / RAPD Methode / gene- tische Variabilität}

\section{REFERENCES}

Anderson RM, May RM (1982) Coevolution of hosts and parasites. Parasitology $85,411-426$

Biasolo A (1992) Lack of allozyme variability among Varroa mite populations. Exp \& Appl Acarol 16, 287-294

De Jong D, Morse RA, Eickwort GC (1982) Mite pests of honey bees. Annu Rev Entomol 27, 229-252 
De Jong D, Gonçalves LS, Morse RA (1984) Dependence on climate of the virulence of Varroa jacobsoni. Bee World 65, 117-121

Delfinado M (1963) Mites of the honeybee in SouthEast Asia. J Apic Res 2, 113-114

Delfinado-Baker M, Houck MA (1989) Geographic variation in Varroa jacobsoni (Acari, Varroidae): application of multivariate morphometric techniques. Apidologie 20, 345-358

Grobov OF, Pulenets NM, Sofronov CL (1980) Geographical variability of the size of the dorsal scutellum in females of Varroa jacobsoni Oud. In: Proceedings of the XXVIIth International Beekeeping Congress, Athens, 1979 (V Harnaj, ed) Apimondia, Bucharest, Roumania, 346-350

Hunt GJ, Page RE Jr (1992) Patterns of inheritance with RAPD molecular markers reveal novel types of polymorphism in the honey bee. Theor App/ Genet $85,15-20$

Koeniger N, Koeniger G, Delfinado-Baker M (1983) Observations on mites of the Asian honeybee species (Apis cerana, Apis dorsata, Apis florea). Apidologie 14, 197-204

Levin S, Pimentel D (1981) Selection of intermediate rates of increase in parasite-host systems. Am Nat $117,308-315$
Ludwig JA, Reynolds JF (1988) Statistical Ecology. John Wiley and Sons, New York, USA

Moretto G, Gonalves LS, De Jong D, Bichutte MZ (1991) The effects of climate and bee race on Varroa jacobsoni Oud infestations in Brazil. Apidologie 22, 197-203

Moritz RFA, Hnel H (1984) Restricted development of the parasitic mite Varroa jacobsoni Oud in the Cape honeybee, Apis mellifera capensis Esch. $Z$ Angew Entomol 97, 91-95

Nation JL, Sanford MT, Milne K (1992) Cuticular hydrocarbons from Varroa jacobsoni. Exp Appl Acarol 16, 331-344

Otten C (1991) Vergleichende Untersuchungen zum Populationswachstum von Varroa jacobsoni Oud in Völkern von Apis mellifera $\mathrm{L}$ unterschiedlicher geographischer Herkunft. PhD Thesis, University of Frankfurt (Main), Germany

Ritter W, De Jong D (1984) Reproduction of Varroa jacobsoni Oud in Europe, the Middle East and tropical South America. Z Angew Entomol 98, 55-57

Ruttner F, Maul V (1983) Experimental analysis of reproductive interspecies isolation of Apis mellifera $\mathrm{L}$ and Apis cerana Fabr. Apidologie 14, 309-327

Williams JGK, Kubelik AR, Livak JK, Rafalski JA, Tingey SV (1990) DNA polymorphisms amplified by arbitrary primers are useful as genetic markers. Nucleic Acids Res 18, 6531-6535 